\title{
PRODUKSI BERAS DI INDONESIA
}

\author{
Hayati Hehamahua
}

Fakultas Ekonomi, Universitas IQRA-BURU Maluku

\begin{abstract}
Crop product especially rice is on of strategic and important commodities in Indonesian economic. The growing needs of rice because of the increasing population from year to year. It seems that domestic rice need projection, as principal food from year to year will increase as explained by USDA in the Agricultural Baseline Projection report to 20014. Import projection showed that until 2014 the domestic need for rice will increase 22-25 tons along with population increase, that is expected will reach 253 populations in 2014 (with growth rate of 1.49\% per year). This research based on secondary data that is related with research variable: land width, productivity, unhulled paddy, rice production, and rice import. The used analysis model to test this hypothesis is Structural Equation Modeling (SEM)

The results by using SEM showed that (1) land influence significantly and positively toward rice production (2) land influence positively and positively productivity (3) productivity influence positively and significantly toward rice production (4) productivity influence the rice import, (5) and production influence the rice import.
\end{abstract}

Key Words: rice analysis in Indonesia, SEM analysis

Produk tanaman pangan khususnya beras adalah salah satu komuditas pangan strategi dan penting dalam perekonomian Indonesia. Masalah perberasan merupakan masalah yang sangat komplek, disaat bangsa Indonesia mengalami krisis multi dimensi yang cukup menyengsarakan rakyat golongan menengah kebawah yang merupakan mayoritas rakyat Indonesia saat ini. Peranan pemerintah dengan lembaga penyanggah (BULOG/DOLOG) yang sebenarnya bertujuan untuk memantau, menjaga dan menstabilkan harga dan pasokan beras di pasar ternyata belum mampu berperan secara signifikan akibat lemahnya kemampuan manajerial pengelola sehingga sering terjadi gejolak harga di pasar yang cukup meresahkan masyarakat. Bulog hanya berperan secara signifikan dalam stabilitas harga gabah pada periode isolasi pasar masa orde baru. Tetapi tidak berperan secara signifikan terhadap stabilisasi harga beras 
konsumen, baik periode isolasi pasar (1967-1998), pasar bebas masa reformasi (19982001), maupun pada pasar terbuka terkendali seperti sekarang (2001-2005).

Kebijakan pemerintah dalam meningkatkan produksi pangan secara nasional sejak tiga Pelita pertama dititikberatkan pada padi atau beras dengan sasaran utama tercapainya swasembada beras. Kebijakan pangan periode tersebut berhasil membawa Indonesia mencapai swasembada beras pada tahun 1984. Namun, dalam perkembangannya ternyata program swasembada yang berorientasi pada beras tersebut relatif rentan terhadap faktor-faktor eksternal, seperti iklim, serangan hama, gejolak pasar dan faktor internal seperti keterbatasan dalam peningkatan produktivitas. Pemerintah terlena dengan penghargaan FAO atas keberhasilan mewujudkan swasembada pangan tersebut, setidaknya hal ini diindikasikan dengan semakin menyusutnya lahan-lahan sawah subur di Pulau Jawa sejak tahun 1984 tersebut untuk berbagai kepentingan industri dan perumahan. Walaupun adanya Keppres No 32 tahun 1992 tentang larangan pengalihan fungsi lahan irigasi teknis di Pulau Jawa, namun tetap gagal mencegah proses konversi lahan-lahan irigasi tersebut. Akibatnya produksi beras nasional turun drastis, terbukti di tahun 1989 kita telah mengimpor beras sebesar 464.449 ton bahkan 10 tahun kemudian kita dikejutkan dengan jumlah impor yang sangat spektakuler yakni sebesar 5,8 juta ton di tahun 1998 (Irawan :2). Penyusutan luasan areal lahan sawah potensial seperti yang terjadi di sepanjang Jalur pantura Jabar dan Banten, diduga mencapai $60.000 \mathrm{ha} /$ tahun, juga turut menyumbangkan peran signifikan terhadap membesarnya senjangan tersebut. Sementara itu alih fungsi sawah untuk perumahan sebesar 58,7 \% terdapat di pulau Jawa. Berdasarkan data Badan Pertanahan Nasional, laju konversi lahan tahun 19992002 rata-rata 110.000 hektar pertahun. Jika rata-rata produktivitas perhektar 4.61 ton gabah kering giling, dalam setahun produksi GKG nasional berkurang sebesar 507.100 ton, atau setara 329.615 ton beras, akibat konversi lahan tersebut (kompas, April 2008 : 17).

Nampaknya proyeksi kebutuhan beras dalam negeri, sebagai pangan pokok (principal food) masyarakat, ditahun tahun mendatang akan terus meningkat seperti 
yang diungkapkan oleh USDA dalam laporan Agricultural Baseline Projection to 20014. Proyeksi import tersebut memperlihatkan bahwa hingga tahun 2014 kebutuhan dalam negeri akan beras terus meningkat antara 22-25 juta ton seiring dengan pertumbuhan penduduk, yang diperkirakan akan mencapai 253 juta jiwa pada tahun 2014 (asumsi laju pertumbuhan $1.49 \%$ /tahun). Berdasarkan data tersebut pula, dari seluruh negara Asia Tenggara, Indonesia satu-satunya negara yang masih melakukan import dan tidak pernah mengeksport. Indonesia semakin jauh tertinggal dengan Vietnam yang terus mampu mengeksport berasnya, bahkan lebih tinggi dibanding Thailand. Data tersebut menunjukkan bahwa sejak pencapaian swasembada beras tahun 1984, produksi beras nasional terus mengalami pelandaian, jika tidak mau dikatakan telah mengalami penurunan. Optimalisasi menajemen stok beras nasional jauh lebih penting daripada membuka kran ekspor beras. Yang menjadi krusial adalah apakah hasil panen saat ini bisa disimpan untuk memenuhi kebutuhan sepanjang tahun?. Berdasarkan data statistik, produksi gabah kering tahun 2007 mencapai 58,5 juta ton, sedangkan produksi beras 33 juta ton. Jika data itu benar, seharusnya kita memilki stok beras nasional yang cukup. Namun perlu disikapi bahwa jika memang produksi beras nasional surplus, sebaiknya pemerintah meningkatkan stok menjaga stabilitas harga domestik, justru kalau sampai ekspor diutamakan harga beras dalam negeri akan melonjak dan membahayakan ketahanan pangan dalam negeri, meskipun harga beras dunia saat ini naik di atas 700 dolar AS per ton.

Konsep ketahanan pangan (food security) lebih luas dibandingkan dengan konsep swasembada pangan, yang hanya berorientasi pada aspek fisik bahan pangan. Beberapa ahli sependapat bahwa ketahanan pangan paling tidak mengandung dua unsur pokok, diantaranya adalah, ketersediaan pangan dan aksebilitas masyarakat terhadap pangan tersebut. Apabila salah satu aspek dari unsur diatas tidak terpenuhi, maka negara tersebut belum dapat dikatakan mempunyai ketahan pangan yang baik. Ketahanan pangan tidak saja di tingkat nasional tetapi sampai ke tingkat rumah tangga pedesaan yang tentunya mencakup fungsi tempat, ruang waktu, dan lebih penting adalah upaya memperkuat strategi ketahanan pangan nasional. Ketersediaan pangan 
sesungguhnya pula merupakan tulang punggung pertahanan nasional itu sendiri. Tanpa pangan yang cukup dan bergizi, generasi penerus pun akan lumpuh secara perlahan. Lebih jauh dari itu, ketergantungan pangan pada negara lain, akan berdampak juga pada tataran hidup seperti ekonomi, sosial, politik dan bahkkan pertahanan keamanan.

Kebutuhan beras yang terus meningkat ini akibat dari jumlah penduduk yang terus bertambah dari tahun ketahun. Jumlah penduduk yang besar ibarat pisau bermata dua, disatu sisi dapat menjadi sumberdaya bagi berkembangnya sektor pertanian yang lebih tangguh dan berdaya saing tinggi. Namun disisi lain, dapat menjadi sumber pemicu kerawanan sosial ketika kebutuhan pokok terhadap pangan tidak tercukupi dengan baik. Ini merupakan efek dari terjadinya kesenjangan antara permintaan dan suplay yang sudah lama berlangsung, harga menjadi tidak terjangkau, dan berakibat pada sebagian masyarakat berpenghasilan dibawah rata-rata tidak mampu menata gizi keluarga dengan baik dan benar. Kesenjangan antara permintaan dan suplay tersebut diyakini kian membesar akibat krisis ekonomi yang terus berkepanjangan, harga pupuk dan pestisida yang kian tinggi, penghapusan subsidi oleh pemerintah, serta deraan iklim terutama kekeringan tahun 2001 dimana kita sempat kehilangan satu kali musim tanam.

Produksi beras menjadi masalah yang cukup serius apabila tidak ditangani dengan sebuah langkah pengamanan yang baik terhadap ketahanan lahan pertanian di Indonesia. Beras sebagai komoditas utama dalam siklus usaha tani yang mampu menyerap tenaga kerja pedesaan dalam jumlah yang signifikan, dan mampu mondorong terciptanya tenaga kerja di sektor perdagangan dan industri pengelolaan disekitar daerah pedesaan maupun perkotaan. Produksi beras dan Produktivitas beras dapat dilihat pada sajian tabel berikut ini.

Tabel I. Perkembangan Produksi, Luas Panen dan Produkstivitas Padi Indonesia Tahun

\begin{tabular}{|c|c|c|c|c|c|}
\hline No & Tahun & Produksi (Ton) & Luas Panen (ha) & $\begin{array}{c}\text { Produktivitas } \\
\text { (ton/ha) }\end{array}$ & $\begin{array}{c}\text { Impor } \\
\text { (ton) }\end{array}$ \\
\hline 1 & 1998 & 49.236 .692 & 11.730 .372 & 4.20 & 11.353 \\
\hline
\end{tabular}




\begin{tabular}{|l|l|l|l|l|l|}
\hline 2 & 1999 & 50.866 .387 & 11.963 .204 & 4.25 & 164.895 \\
\hline 3 & 2000 & 51.898 .852 & 11.793 .475 & 4.40 & 104.692 \\
\hline 4 & 2001 & 50.460 .782 & 11.449 .997 & 4.39 & 142.558 \\
\hline 5 & 2002 & 51.489 .694 & 11.521 .166 & 4.47 & 166.579 \\
\hline 6 & 2003 & 52.078 .830 & 11.477 .357 & 4.54 & 205.062 \\
\hline 7 & 2004 & 54.060 .817 & 11.908 .398 & 4.54 & 178.599 \\
\hline
\end{tabular}

Sumber : Badan Pusat Statistik dari berbagai tahun ( diolah )

Dari tabel 1 diatas terlihat produksi padi Indonesia dari tahun 1998 -2004 menunjukkan tren yang semakin meningkat sebesar 54.060.817 ton naik sekitar 8.9\% ( \pm 4.824 .125 ton) namun luas panen cendrung menurun dari 11.730 .372 ha pada tahun 1998 menjadi sekitar 11.47.357 ha pada tahun 2003. Bila ditinjau dari produksi beras secara material/fisik memberikan gambaran bahwa beras adalah komoditas strategis, tetapi bernasib tragis, terutama bagi petani sebagai produsennya. Fakta yang sangat mengherankan adalah impor pada tahun 2003 cukup memprihatinkan sebagai negara agraris.

Beras merupakan makanan pokok bagi bangsa Indonesia sehingga sangat berpengaruh terhadap kestabilan nasional, maka intervensi pemerintah sangat diperlukan untuk mengatasinya. Karena menyangkut kepentingan produsen dan konsumen yang kedua-duanya harus dilindungi. Bertitik tolak pada latar belakang tersebut diatas, maka dalam penelitian ini penulis mencoba mengkaji permasalahan terkait dengan analisis produksi beras di Indonesia antara lain variabel-variabel yang berpengaruh terhadap produksi beras di Indonesia dan seberapa besar pengaruh variabel-variabel tersebut terhadap produksi beras di Indonesia.

\section{PRODUKSI}

\section{Pengertian}

Secara umum "produksi" mempunyai pengertian pemanfaatan sumber daya yang mengubah suatu bentuk barang menjadi barang yang lain atau dapat mengubah bentuk satu ke bentuk yang lain. Input adalah barang dan jasa yang digunakan sebagai masukan pada suatu proses produksi, sedangkan output adalah barang atau jasa yang dihasilkan dari suatu proses produksi. Pada intinya produksi adalah suatu proses mengubah input menjadi output sehingga nilai barang tersebut bertambah. Input dapat 
terdiri dari barang atau jasa yang digunakan dalam proses, dan output adalah barang atau jasa yang dihasilkan dari suatu proses produksi.

\section{Fungsi produksi}

Fungsi produksi menggambarkan semua metode produksi yang efisien secara tehnis dalam artian menggunakan kualitas bahan mentah yang minimal, tenaga kerja minimal, dan modal minimal. Konsep fungsi produksi yang bersifat tehnis ini masih perlu didukung oleh konseptualisasi input-input atau faktor-faktor produksi lainnya yang lebih luas, seperti faktor kecakapan menajerial dan motivasi tenaga kerja. Fungsi produksi menunjukkan seberapa besar pemakaian input untuk menghasilkan sejumlah output. Dengan demikian maka jelas bahwa besar kecilnya output yang di hasilkan sangat tergantung pada seberapa besar pemanfaatan input yang di gunakan. Jadi kapasitas produksi dinyatakan oleh fungsi produksi yaitu hubungan perimbangan antara hasil produksi total di satu pihak dan sejumlah faktor produksi di lain pihak.

Hubungan antara input dan output dapat di formulasikan kedalam suatu fungsi produksi yang dalam bentuk matematis : $Q=f(K, L, M)$.

Fungsi produksi harus efisein secara tehnis dan tunduk kepada "the low of diminishing returns". Fungsi produksi ini dapat di gambarkan dalam grafik di bawah ini :

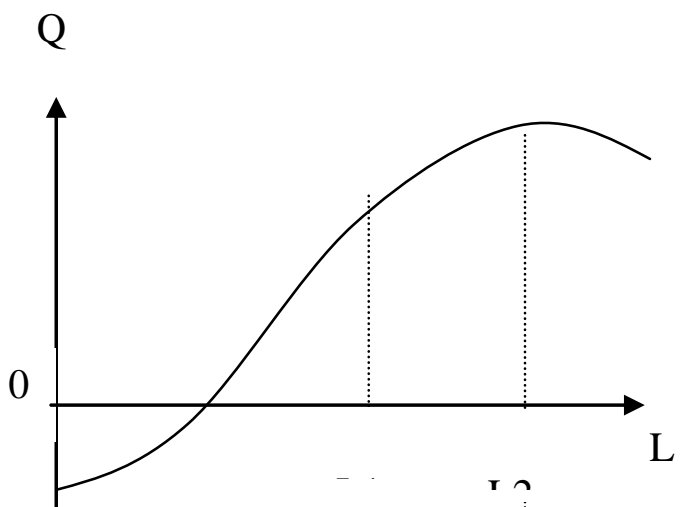

Gambar I :Kurva produksi jangka pendek dengan pendekatan I input variabel

Pada gambar di atas menunjukkan tiga tahap dalam proses produksi yaitu:

1. Saat input variable nol, kualitas produksi juga nol.

2. Semakin banyak kualitas input variabel di gunakan, maka semakin meningkat kualitas produksi ( antara 0-L1) positif naik. 
3. Bila terjadi penambahan kuantitas produksi diikuti dengan perubahan input variabel dan di kombinasikan dengan input lain tetap, maka pada titik tertentu kuantitas produksi menurun (L1- L2) lereng kurva positif terus menurun.

\section{Kerangka Pikir Dan Hipotesis}

Beras mempunyai kedudukan dan peranan yang sangat penting dalam kehidupan bangsa Indonesia, mengingat makan pokok mayoritas masyarakat Indonesia adalah beras. Persoalan pangan khususnya beras berkaitan erat dengan kehidupan yang lebih luas, seperti sosial ,politik dan bahkan pertahanan keamanan. Oleh karena itu pemerintah perlu menghindari terjadinya krisis beras seperti yang terjadi pada masa-masa yang lalu. Peningkatan suplay pangan dengan dukungan produksi dan produktivitas mutlak diperlukan untuk memenuhi permintaan pangan yang semakin tinggi dari tahun ketahun, sehingga kran impor yang selama ini di angung-angungkan bisa di tekan dengan sebuah ungkapan " martabat bangsa lebih berharga dari segala-galanya.

Adapun kerangka pikir dalm penelitian adalah sebagai berikut

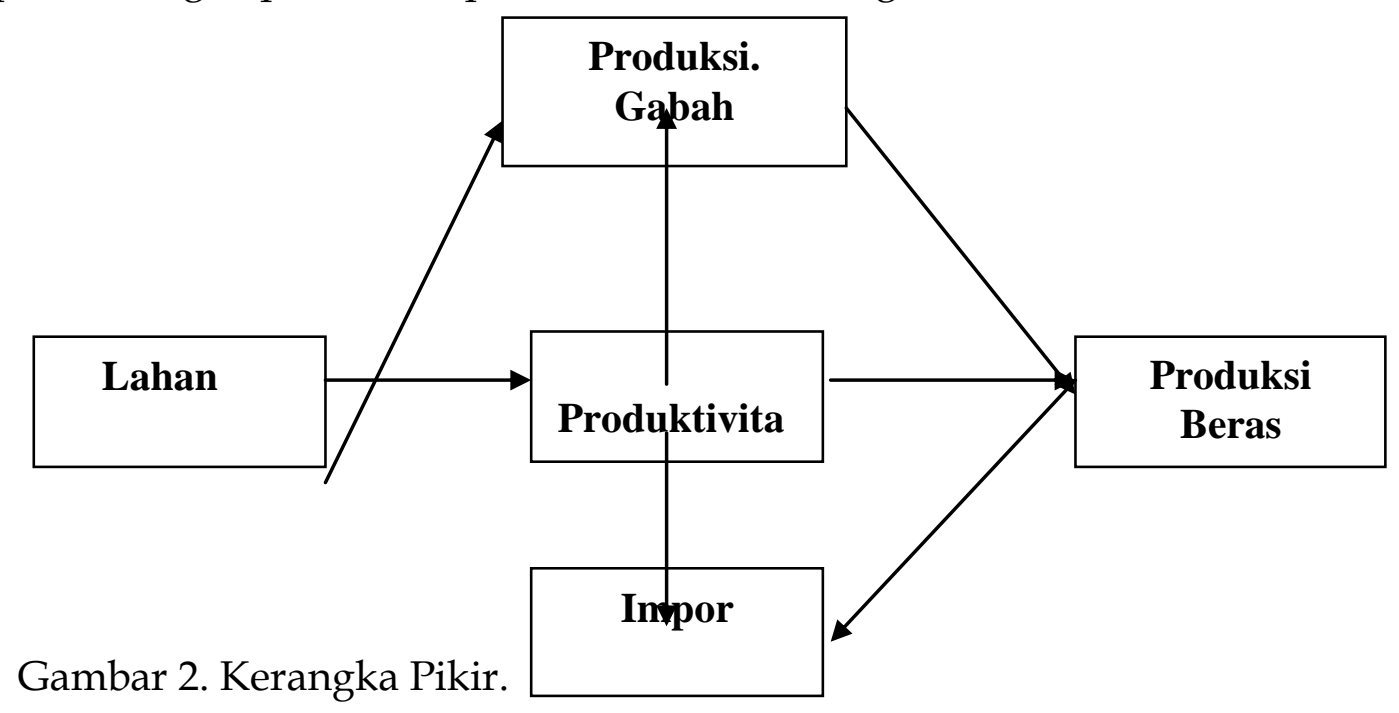

\section{METODE}




\section{Metode Pengambilan Data}

Penelitian ini bersumber pada data sekunder yang berkaitan dengan variabel penelitian yaitu: luas lahan, produktivitas, produksi gabah, produksi beras, dan impor beras tahun 1998 hingga 2004 yang dipublikasikan oleh instansi-instansi terkait, di antaranya adalah Departemen Pertanian, Bulog, BI, FAO, dan lain-lain.

\section{Metode Analisis Data}

Dengan memperhatikan model penelitian, kerangka teoritis dalam penelitian yang telah diformulasikan sebelumnya, teknik yang tepat untuk digunakan dalam penelitian ini, adalah model persamaan structural equation modeling (SEM). Model persamaan struktural ini pada prinsipnya merupakan analisis multivariate yang menggambarkan penerapan dari beberapa model secara kompak Ferdinand (2002:7) yaitu model Analisis faktor (Factor analysis). model Analisis Jalur (Path Analiysis) dan model Analisis Regresi (Regression Analiysis).

Structural Equation Modeling (SEM) menguji suatu rangkaian hubungan saling ketergantungan antar variabel secara simultan. Teknik ini sangat berguna apabila suatu variabel dependen menjadi variabel independent dalam hubungan persamaan selanjutnya. Alasan digunakan Structural Equation Modeling (SEM) dalam penelitian ini adalah berdasarkan pertimbangan bahwa :

1. SEM memberikan metode langsung berkaitan dengan hubungan ganda secara simultan sekaligus memberikan efisiensi analisis statistika.

2. Kemampuannya untuk hubungan secara komprehensif dan memberikan suatu bentuk transisi analisis explanatory menuju analisis comfirmatory.

Langkah-langkah yang dilakukan dalam menggunakan Structural Equation Modelling (SEM) di antaranya adalah:

1) Pengembangan model teoritis

Dalam langkah pengembangan model teoritis, dilakukan serangkaian eksplorasi ilmiah melalui telaah pustaka guna mendapatkan justifikasi atas model teoritis yang akan dikembangkan. SEM digunakan bukan untuk menghasilkan sebuah model, 
tetapi digunakan untuk mengkorfirmasi model teoritis tersebut melalui data empirik.

2) Pengembangan diagram alur (path diagram)

Dalam langkah kedua ini, model teoritis yang telah dibangun pada tahap pertama akan digambarkan dalam sebuah path diagram, yang akan mempermudah untuk melihat hubungan-hubungan kausalitas yang ingin diuji. Dalam diagram alur, hubungan antar konstruk akan dinyatakan melalui anak panah. Anak panah yang lurus menunjukkan sebuah hubungan kausal yang langsung antara satu konstruk dengan konstruk lainnya. Sedangkan garis-garis lengkung antar konstruk dengan anak panah pada setiap ujungnya menunjukkan korelasi antara konstruk.

3) Konversi diagram alur ke dalam persamaan struktural dan model pengukuran.

Persamaan yang di dapat dari diagram alur yang dikonversi terdiri dari :

- Persamaan struktural (structural equation), yang dirumuskan untuk menyatakan hubungan kausalitas antar berbagai konstruk.

Variabel endogen $=$ variabel eksogen + variabel endogen + error

- Persamaan spesifik model pengukuran (measurement model), dimana harus ditentukan variabel yang mengukur konstruk dan menentukan serangkaian matriks yang menunjukkan korelasi yang dihipotesakan antar konstruk atau variabel.

Berdasarkan kerangka pemikiran yang telah dikemukakan pada bagian terdahulu maka persamaan struktural yang akan dicari dan diuji koefisiennya adalah sebagai berikut :

Persamaan Struktural

1.Produksi $=\lambda_{1}$ luas lahan $\lambda_{2}+\varepsilon_{1}$

2. Gabah $=\lambda_{3}$ luas lahan $+\lambda_{4}$ Produksi Beras $+\varepsilon_{2}$

3. Beras $=\lambda_{5}$ Produksi beras $+\lambda_{6}$ Produksi Gabah $+\varepsilon_{3}$

4.Impor Beras $=\lambda_{7}$ Produktivis $+\lambda_{8}$ Produksi Beras $+\varepsilon_{4}$ 
Dimana:

$\lambda_{1}=$ loading factor (regression weight) pengaruh luas lahan terhadap produksi gabah

$\lambda_{2}=$ loading factor (regression weight) pengaruh luas lahan terhadap produkstivitas

$\lambda_{3}=$ loading factor (regression weight) pengaruh produsktivitas terhadap produksi beras

$\lambda_{4}=$ loading factor (regression weight) pengaruh produktivitas terhadap impor beras.

Uji hipotesis ini diuji dengan uji regression weight. Uji ini sama dengan uji t (uji parsial) dalam multiple regression, uji ini dilakukan dengan cara membandingkan nilai $t$ hitung dengan $\mathrm{t}$ tabel , dengan ketentuan: jika $t_{\text {hitung }}>t_{\text {tabel }}$ berarti variabel tersebut signifikan dan jika $t_{\text {hitung }} \leq t_{\text {tabel }}$ berarti variabel tersebut tidak signifikan. Agusty (2000: 75) menjelaskan bahwa $t_{\text {hitung }}$ identik dengan C.R (critical ratio) yang diuji dengan nilai probabilitas $\mathrm{p}$, dimana jika $\mathrm{p}<0,05$ menunjukkan pengaruh yang signifikan dan jika $\mathrm{p}>0,05$ menunjukkan tidak signifikan.

\section{HASIL dan PEMBAHASAN}

\section{Hasil Analisis Structural Equation Modeling}

\section{Uji Goodness of Fit Model}

Model teoritis pada kerangka konseptual penelitian, dikatakan fit jika didukung oleh data empirik. Hasil pengujian goodness of fit overall model, guna mengetahui apakah model hipotetik didukung oleh data empirik, diberikan pada tabel di bawah ini. 


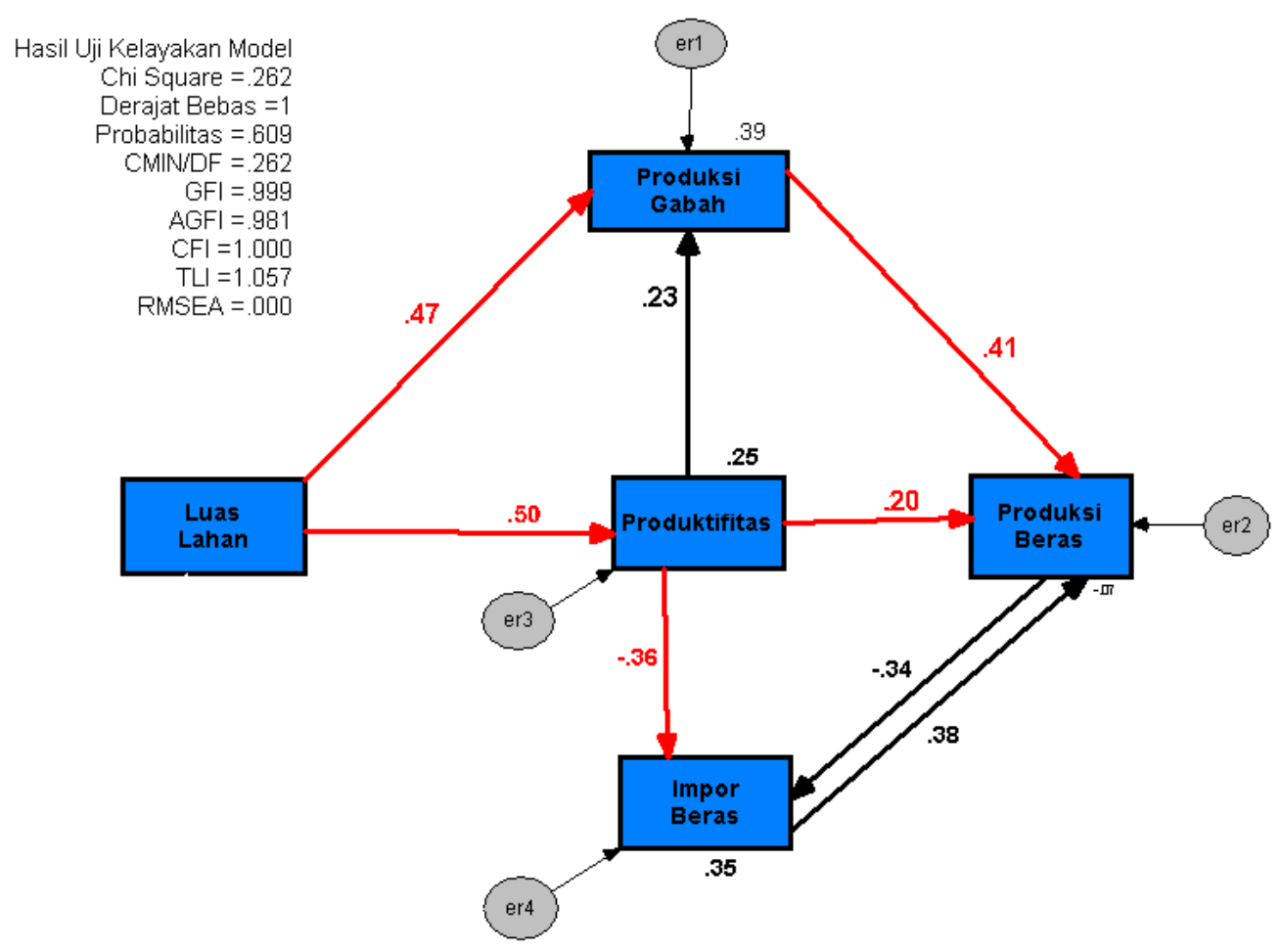

Tabel 1: Hasil Pengujian Goodness of Fit Overall Model

\begin{tabular}{|l|l|l|l|}
\hline Cut-of value & Kriteria & Hasil Model & Keterangan \\
\hline kecil & Khi Kuadrat & 0,262 & \multirow{2}{*}{ Model Baik } \\
\hline$\geq 0,05$ & p-value & 0,809 & Model Baik \\
\hline$\leq 2,00$ & CMIN/DF & 0,262 & Model Baik \\
\hline$\geq 0,90$ & GFI & 0,999 & Model Baik \\
\hline$\geq 0,90$ & AGFI & 0,981 & Model Baik \\
\hline$\geq 0,95$ & TLI & 1,057 & Model Baik \\
\hline$\geq 0,95$ & CFI & 1,000 & Model Baik \\
\hline$\leq 0,08$ & RMSEA & 0,000 & \\
\hline
\end{tabular}

Sumber: Data dioleh

Hasil pengujian Goodness of Fit Overall berdasarkan tabel di atas, dapat disimpulkan bahwa dari ketujuh kriteria tersebut di atas, hampir semua kriteria menunjukkan hasil yang memuaskan, sehingga model dikatakan baik dan dapat digunakan untuk pengujian hipotesis

\section{Pengujian Asumsi Model SEM}

Terdapat beberapa pengujian asumsi yang dilakukan dalam SEM, yaitu normalitas dan linieritas. Asumsi normalitas multivariate diuji dengan bantuan software AMOS 0.4, menunjukkan bahwa secara multivariate data berdistribusi normal. Hal ini 
diindikasikan pada nilai critical ratio sebesar -0,261, dengan nilai kritis $Z_{\text {hitung }}$ untuk $\alpha$ $5 \%$ adalah sebesar 1,96. Karena seluruh nilai mutlak CR $<1,96$ maka asumsi normalitas multivariate dipenuhi. Pengujian asumsi linieritas dilakukan dengan metode Curve Fit, dihitung dengan bantuan software SPSS. Rujukan yang digunakan adalah prinsip parsimony, yaitu bilamana model linier signifikan, atau seluruh model tidak signifikan digunakan sebagai dasar pengujian model dikatakan linier. Spesifikasi model yang digunakan sebagai dasar pengujian adalah model linier, kuadratik, kubik, inverse, logaritmik, power, compound, growth, dan eksponensial. Secara ringkas disajikan pada tabel berikut, bahwa seluruh hubungan adalah linier.

Tabel 2: Hasil Pengujian Asumsi Linieritas

\begin{tabular}{|c|c|c|c|}
\hline $\begin{array}{l}\text { Variabel } \\
\text { Bebas }\end{array}$ & $\begin{array}{l}\text { Variabel } \\
\text { Terikat }\end{array}$ & $\begin{array}{l}\text { Hasil Pengujian }(\alpha= \\
0,05)\end{array}$ & Keputusan \\
\hline Luas Lahan & Produksi Beras & $\begin{array}{ll}\text { Seluruh } & \text { model } \\
\text { signifikan } & \end{array}$ & Linier \\
\hline Impor Beras & Produktivitas & model & Linier \\
\hline Luas Lahan & Produksi Gabah & Model linier signifikan & Linier \\
\hline $\begin{array}{l}\text { Produksi } \\
\text { Beras }\end{array}$ & Produksi Gabah & $\begin{array}{ll}\text { Seluruh } & \text { model } \\
\text { signifikan } & \end{array}$ & Linier \\
\hline Produktivitas & Produksi Beras & Model linier signifikan & Linier \\
\hline Produktivitas & Impor Beras & $\begin{array}{l}\text { Model linier tidak } \\
\text { signifikan }\end{array}$ & Linier \\
\hline $\begin{array}{l}\text { Produksi } \\
\text { Beras }\end{array}$ & Impor Beras & Model Linier Signifikan & Linier \\
\hline Impor Beras & Produksi Beras & $\begin{array}{l}\text { Model Linier Tidak } \\
\text { Signifikan }\end{array}$ & Liner \\
\hline
\end{tabular}

Sumber: Data diolah

\section{Pengujian Pengaruh Antar Variabel}

Pengujian hipotesis dilakukan dengan uji $\mathrm{t}(t$ test) pada masing-masing jalur pengaruh langsung secara parsial. Tabel 3 menyajikan hasil pengujian hipotesis pengaruh langsung.

Tabel 3: Hasil Pengujian Hipotesis Pengaruh Antar Variabel

\begin{tabular}{|l|l|l|l|c|l|}
\hline Variabel Bebas & $\begin{array}{l}\text { Variabel } \\
\text { Terikat }\end{array}$ & $\begin{array}{l}\text { Loading } \\
\text { Factor }\end{array}$ & $\begin{array}{l}\text { Critical } \\
\text { Ratio }\end{array}$ & $\begin{array}{l}\text { p- } \\
\text { value }\end{array}$ & Keterangan \\
\hline Produksi & Luas lahan & $\mathbf{0 . 5 0 3}$ & 5.307 & 0.000 & Signifikan \\
\hline
\end{tabular}




\begin{tabular}{|l|l|l|l|l|l|}
\hline Gabah & Luas lahan & $\mathbf{0 . 4 7 2}$ & 4.741 & 0.000 & signifikan \\
\hline Gabah & Produksi Beras & $\mathbf{0 . 2 3 2}$ & 2.335 & 0.020 & Signifikan \\
\hline Beras & Produksi & $\mathbf{0 . 1 9 9}$ & 0.946 & 0.344 & Signifikan \\
\hline Beras & Gabah & $\mathbf{0 . 4 0 5}$ & 2.501 & 0.012 & signifikan \\
\hline Impor & Produktivitas & $\mathbf{- 0 . 3 6 0}$ & -3.941 & 0.000 & signifikan \\
\hline Produksi Beras & Impor Beras & $\mathbf{- 0 . 3 4 1}$ & -2.092 & 0.036 & \\
\hline Impor Beras & Produksi Beras & $\mathbf{0 . 3 7 9}$ & 1.103 & 0.270 & \\
\hline
\end{tabular}

Sumber: Data diolah

Hasil pengujian hipotesis jalur-jalur pengaruh langsung juga dapat dilihat pada gambar diagram jalur sebagai berikut.

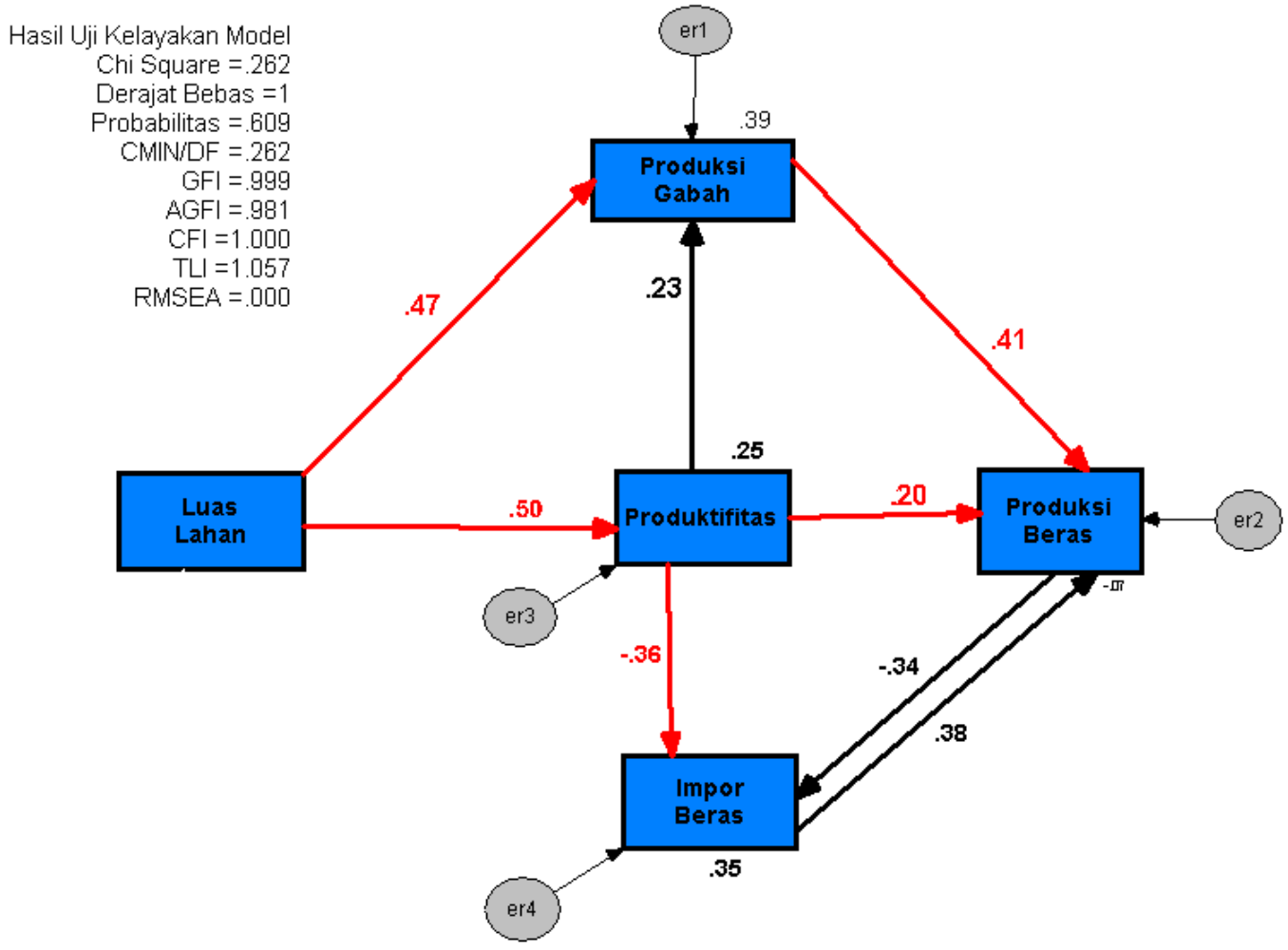

Gambar 3: Diagram Jalur Hasil Pengujian Hipotesis

Berdasarkan Tabel 3. dan Gambar 3 maka diperoleh hasil pengujian hipotesis seperti pada uraian berikut.

\section{Hipotesis : Luas lahan berpengaruh terhadap produktivitas}

Hasil analisis koefisien path pengaruh langsung antara luas lahan dengan produktivitas diperoleh nilai loading factor sebesar 0,503 dengan p-value sebesar 0,000, maka terdapat cukup bukti untuk menerima hipotesis bahwa "luas lahan mempengaruhi produktivitas". artinya semakin besar luas lahan, mengakibatkan 
semakin tinggi pula produktivitas. Hasil ini didukung oleh penelitian yang dilakukan oleh Marlina di Jawa Barat, menemukan bukti bahwa pertumbuhan produksi beras nasioanal lambat atau bisa dikatakan stagnan, karena adanya konversi lahan produktif menjadi lahan perumahan dan indusrti.

\section{Hipotesis : luas lahan berpengaruh terhadap produksi gabah}

Hasil analisis koefisien path pengaruh langsung antara luas lahan dengan produksi gabah diperoleh nilai loading factor sebesar 0,472 dengan p-value $<0,000$. Maka terdapat cukup bukti untuk menerima hipotesis bahwa "luas lahan mempengaruhi produksi gabah"., artinya semakin besar luas lahan, mengakibatkan semakin tinggi pula produksi gabah. Hasil ini didukung oleh penelitian yang dilakukan oleh Marlina Jawa Barat, menemukan bukti bahwa. Dalam priode 1983 -1993, luas lahan pertanian mengalami penurunan dari 16,7 juta hektar menjadi 15,6 juta hektar, atau sekitar 110.000 hektar pertahun. Apabila kondisi ini terjadi pada semua daerah, maka dipastikan produksi gabah mengalami penurunan.

\section{Hipotesis :Produksi Gabah berpengaruh terhadap produksi beras}

Hasil analisis koefisien path berpengaruh terhadap produksi beras dengan diperoleh nilai loading factor sebesar, 232 dengan p-value $<0,020$. Maka terdapat cukup bukti untuk menerima hipotesis bahwa "produksi gabah mempengaruhi produksi beras". Artinya semakin tinggi nilai produksi gabah, maka mengakibatkan semakin tinggi pula produksi beras.

\section{Hipotesis : Produktivitas berpengaruh terhadap produksi Beras}

Hasil analisis koefisien path pengaruh langsung antara produktivitas dengan produksi gabah diperoleh nilai loading factor sebesar 2,32 dengan p-value $<0,309$. Maka terdapat cukup bukti untuk menerima hipotesis bahwa "produktivitas mempengaruhi produksi beras"., artinya semakin tinggi produktivitas mengakibatkan semakin tinggi pula produksi beras yang dihasilkan

\section{Hipotesis : Produktivitas berpengaruh terhadap impor beras}


Hasil analisis koefisien path pengaruh langsung antara produktivitas terhadap impor beras diperoleh nilai loading factor sebesar -0395 dengan p-value sebesar -4508. Dengan demikian, impor sangat dipengaruhi oleh produktivitas, atau hipotesis yang menyatakan "terdapat pengaruh produktivitas terhadap impor beras" dapat diterima. Dengan kata lain, produktivitas mempengaruhi impor beras, hubungan kedua variabel ini adalah negatif, artinya semakin tinggi produktivitas, mengakibatkan semakin rendah impor beras. Sebaliknya, bila semakin rendah produktivitas, mengakibatkan semakin tinggi impor beras. Dari hipotesis yang tersebut, saling berhubungan antara variabel satu dengan variabel yang lain, dimana produksi sangat ditentukan oleh seberapa besar ketersediaan lahan, seberapa besar tingkat produkstivitas dalam mengahasilkan produksi beras, karena produktivitas yang tinggi itulah akan mampu menekan impor beras.

\section{KESIMPULAN DAN SARAN}

\section{Kesimpulan}

Penelitian ini berusaha menguji hipotesis yang berkaitan dengan faktor yang mempengaruhi produksi beras di Indonesia. Dengan menggunakan model Structural Equation Modeling (SEM), maka hasil penelitian dapat disimpulkan sebagai berikut ini :

1. Ketersediaan pangan sesungguhnya merupakan tulang punggung pertahanan nasional. Tanpa pangan yang cukup dan bergizi, generasi penerus pun akan lumpuh secara perlahan. Jauh dari itu, ketergantungan pangan pada negara lain, berdampak juga pada tataran hidup yang lainnya.

2. Hasil pengujian menunjukkan bahwa secara parsial faktor produktivitas sangat berpengaruh terhadap impor beras, begitupun faktor lahan sangat berpengaruh terhadap produksi dan produktivitas

\section{Saran}

1. Kekayaan sumberdaya alam yang memadai, baik tanah, air dan iklim dengan sifatnya yang unik memberikan peluang besar bagi Indonesia untuk terus menyediakan pangannya 
secara kontinyu dengan mutu yang tinggi. Untuk itu kerjasama antar berbagai bidang dan keahlian harus dilakukan agar mampu mewujudkannya.

2. Optimalisasi menajemen stok nasional perlu dibenahi agar pemerintah mampu menekan tingkat impor beras yang merupakan urat nadi dari pangan nasional.

\section{DAFTAR PUSTAKA}

Adiningsih.1991. Ekonomi Mikro. Edisi Pertama. Yogyakarta: BPFE.

Andi Irawan Integrasi 2005. Pasar Beras di Indonesia data Internet : website, Fe. Unsri.ac,id Akbar. M. 2002. Model Simulasi Penyediaan Kebutuhan Beras Nasional.

Balai Pengkajian Teknologi Pertanian Sulawesi Tenggara 2006. Permintaan beras kepala di Kota Kendari. Data internet, Wibsite: climatechange Menih.go.id

Dwijono, at, all. 2007. Kesejahteraan Petani dan Peningkatan Ketersediaan Pangan. Data Internet,Wibsite : www. Jurnal Ekonomi Rakyat

Ferizal dan Zulham.2007. Kebijakan Operasi Pasar dan Pasar Beras di Nanggro Aceh Darusasalam. Data Internet, Wibsite : www. Geocities.com

Ferdinad. 2002. Structural Eqution Model Dalam Penelitian Manajemen. Semarang: Badan Penerbit Universitas Diponegoro.

Jurnal Ekonomi Ideologi. 2008. Ekspor Beras Bahayakan Ketahanan Pangan. Data Internet, Wibsite : Digilib.uni.com.ac.id.

Ketahanan Pangan 2001. Data Internet, Wibsite : www. Pustaka -Deptan.go.id.

Konpas. 2008. Konversi Tak Terkendali.

Lincolin. 1991. Ekonomi Mikro. Edisi Kedua. Yogyakarta: BPFE.

Mardianto at,all, 2005. Dinamika Pola Pemasaran Gabah dan Beras di Indonesia.

Mubyarto. 1986. Pengantar Ekonomi Pertanian. LP3Es, Jakarta.

Ravianto J.1985. Produktivitas dan Teknologi. Lembaga Sarana Informasi Usaha dan Produktivitas Edisi Pertama. Jakarta.

Rahmawati. Dan Moeis .2005. Estimasi Fungsi Permintaan Makanan Dalam Analisa diversifikasi Pangan Untuk menurunkan permintaan beras di Provinsi Jawa Barat. Data Internet, Wibsite istecs.org.

Suwandi 2005. Analisis dampak Subsidi Benih Padi. Data internet, Wibsite : http//:www.digilih.ui.edu/opac. 
Siregar.Masjidin. 2001. Analisi Kebijakan Perdaganagn Komoditas Pangan.Data Internet, Wibsite : www/ Pustaka-Deptan .go.id.

Swastika Sandra. 1999. Penerapan Model Dinamis Dalam Sistem Penawaran dan Permintaan Beras di Indonesia. Data Internet,Wibsite : www. Bapenas.go.id.

Suresmiathi, Ayu. 2007. Elastisitas Pengeluaran Dan Permintaan Terhadap Pangan di Daerah Bali. Data internet, Wibsite : www. Litbang.Deptan.go.ig

Syahbudin. 2005. Jangan Lupa Swasembada Pangan.Data Internet, Website : http:// Wiraswast. net.

Zulhadi dan Ferizal 2001. Kebijakan Operasi Pasar dan Pasar Beras di Nanggroe Aceh Darrussalam . data internet, Wibsite: http.www.

Widodo.Drajad. 2004. Mencari Akar Masalah Beras : Data Internet, Wibsite : http: //Wiraswasta net 